\author{
BULETINUL INSTITUTULUI POLITEHNIC DIN IAŞI \\ Publicat de \\ Universitatea Tehnică „Gheorghe Asachi” din Iaşi \\ Volumul 67(71), Numărul 1, 2021 \\ Secţia \\ CONSTRUCTTII. ARHITECTURĂ \\ DOI: $10.2478 /$ bipca-2021-0010

\section{sciendo}

\title{
NOTES ABOUT BF SLUDGE AS A POTENTIAL USE AS FILLER IN ASPHALT MIXTURE COMPOSITION
}

BY

\section{DANA-RAMONA NANEA*}

\author{
„Gheorghe Asachi” Technical University of Iaşi, Faculty of Civil Engineering and Building \\ Services, Iasi, Romania
}

Received: January 27, 2021

Accepted for publication: March 28, 2021

\begin{abstract}
The purpose of the research carried out is to develop a new perspective on a material resulting from steelworks. Currently, the blast furnace sludge from Galati is used as granular material in road construction generally at foundation layer. The bf sludge has the chemical and mechanical potential to be used as filler in bituminous mixture, as a result of its particular composition which does not interact with bitumen, and it has the ability to be crushed in particle fractions. The main constituents of the bf sludge are different oxides, as calcium, aluminium, iron, magnesium, manganese oxides, sulphide. The raw material is homogenous, with no impurities and it is not toxic for the environment. The characteristics of the filler sample was analysed, and its results is compared with standard specifications. The bf sludge was ground into very fine granules, under 2 $\mathrm{mm}$, and then tested in laboratory in standard conditions.
\end{abstract}

Keywords: bf sludge, artificial aggregate, bituminous mixture, filler, sample.

\section{Introduction}

The bf sludge has the ability to be used as construction material in Romania, considering the specifications of Directive 89/106/EEC on the harmonisation of the laws, technical regulations and administrative specifications

\footnotetext{
* Corresponding author;e-mail: dana-ramona.nanea@student.tuiasi.ro (C) 2021 Dana-Ramona Nanea

This is an open access article licensed under the Creative Commons Attribution-NonCommercialNoDerivatives 4.0 International License (CC BY-NC-ND 4.0).
} 
of the Member States relating to products for constructions, the considerations of Ordinance 20/18.08.2010 on the establishment of measures for the uniform application of EU legislation harmonising the conditions for the marketing of products, as well as the specifications of HG 622/2004 with amendments and subsequent additions on the establishment of the conditions for placing construction products on the market. BF sludge is produced in the Liberty Galati plant and meets the characteristics of building materials according to specifications of SR EN 1220:2002+A1/2008, SR EN 13043:2002/AC:2004, SR EN 13242:2002+A1/2008, SR EN 13139:2002/AC:2004, SR EN 133831/2002/AC:2004, SR EN 13450:2002/AC:2004. BF sludge is an artificial aggregate that can replace natural aggregates in the process of obtaining raw materials for construction industry. It is very commonly found at foundation works of various infrastructure works. As for the source of provenance, the bf sludge is obtained in the metallurgical industry, at the SC Liberty Galati steel plant, located in southeastern Romania, in the city of Galati. The product obtained is temporarily stored; in the context of the current environmental issues, the need to capitalize this material, considered a waste, led to a much closer analysis of the physico-chemical properties of the BF sludge in terms of the standards mentioned above, studying the ability to use this material as well as the domain in which it can be used. Currently, the BF sludge storage dump of the plant is located in Galati municipality, on its own storage platform. SC Liberty Galati exploits the bf sludge, performing the processes of extraction, selection of sludge from storage dump, loading in crushing and sorting plants, crushing and sorting in different size fractions, storage of the materials of different size fractions obtained until revaluation. The crushed stone material is used mainly as granular raw material, as components of different material used in construction. Favorable effects of the use of bf sludge as building material includes reducing or even removing the dimensions of the storage dump, conservation of natural resources by limiting their use in industry (natural aggregates from quarries) and by redesigning the materials commonly used in construction works infrastructure, inclusion in the waste management plans of the sludge new methods for revaluation. So far, the ability to use bf sludge as filler has not been investigated in research of asphalt mixes formulas for bituminous layers.

\section{The role of filler in asphalt mixture}

The filler is very fine granular material from the mineral skeleton in asphalt mixtures, a fraction that passes $100 \%$ through $2 \mathrm{~mm}$ sieve, and on the $0.063 \mathrm{~mm}$ sieve, minimum $70 \%$. Therewith, apart from its granulometric role in the mixture, over time it has been found that has an influence on bitumen, due to the bitumen - filler interaction. One of its role is to increase plasticity field limits of bitumen and increases the adhesion to the coarse aggregate. It also increases the inner friction and cohesion of bitumen and as the effect of these, BF sludge 
filler improves the behavior of mixture at statistic loads as well as breaking. In the asphalt mixtures, the bitumen mixed with the filler has significantly better characteristics than common bitumen, he ages much harder and he keep their properties for a long time. Like the other components of asphalt mixtures, the filler is dosed in precise quantities. When the dosage is correctly chosen, the filler increases the specific surface of the natural aggregate, increases the mixture compactness, and by the filler- bitumen mixing mixture which is made when mixing, the resistance of the asphalt mixture is increased (the stability) and reduces the deformation of the mixture at high temperatures. The role of the filler in asphalt mixtures is given both by the physical, mechanical and chemical characteristics of the filler as well as by its dosage in the mineral skeleton and by the ratio between the filler and bitumen. As the ratio is at the upper limit imposed, both the physical-mechanical strengths of the mix as well as durability, increase. The thickness of the bitumen film that covers the filler particles, thickness which is determined by the bitumen dosage in the total mixture, influences the characteristics of the mixture. It is necessary to study more closely the filer bitumen interaction, which will be carried out in the second part of the paper, focused on the study of the asphalt mix prepared. The ability to use filler in asphalt mixtures is determined by laboratory tests on both the material taken as such (laboratory sample) and the prepared mixture. From the tests carried out directly on filler, its characteristics are expressed, which refers strictly to the material and by determining the characteristics of the asphalt mixtures it can be deduced if the filler has fulfilled its role in the mixture. Dosed correctly, the filler performs its role in asphalt mixtures, but the excess filler can be harmful, as follows: very often it is possible to be formed in the composition of asphalt mixture clod of filler, or the mixture itself can be very difficult to work with; this can lead to insufficient compaction of the layer which favors the infiltration of water into the gaps between the granules, and consequently their disassembly. In any case, granules of mineral aggregate must be coated with a thin film of bitumen. The thicker the film, the more deformed the mixtures and the shear resistance decreases. Obtaining a fine bitumen film can be done by filing. In this thesis we will analyze how the properties of the filler obtained from the granulated sludge are reflected in the physical-mechanical characteristics of the mixtures, by following some indicators such as: filer binder interaction (filer / bitumen ratio), rut depth, the relationship between the filler dosage - the volume of voids in the asphalt mixtures, cohesion of asphalt mixtures, workability, resistance to permanent deformation (ruts) of asphalt mixtures prepared with bf sludge filler. Known assumptions regarding the influence of fillers on the asphalt mix are: the stability and creep of the asphalt mixtures vary significantly with the filler dosage, the filler improves the viscosity of the binder, as a result of its granulosity, reduces the volume of voids in the asphalt mix, the filer - bitumen interaction (the filer - bitumen ratio) has a significant influence on the physicalmechanical properties of the asphaltic mixtures. If the filler-bitumen ratio is 
increased, keeping the percentage of binder constant, then the mixture obtained will be more rigid, will have a high stability and low deformation, and during the paving process the mixture will require mixing and a more energetic compaction. The increased rigidity is given by increasing the softening power of the filamentized bitumen and reducing the volume of apparent voids. The excess filler generally leads to a difficult to work mix, possibly even with uncoated granules, which favor water penetration. If the ratio of filler-binder decreases keeping the percentage of binder constant, then the mixture will be more elastic, will have a low stability and a high deformation. The mixture will deform at the action of a low force, especially at high temperature. Also, a low content of filler favors the leakage of the binder from the surface of the granules due to its low viscosity. Therefore it can be easily concluded that both the physical-mechanical and chemical properties and the filler dosage will have an influence on the characteristics of asphalt mixtures. The characteristics of the bf sludge obtained at SC Liberty Galati, from which it is desired the processing and obtaining of filler in the laboratory are stated in the certificate for factory production control, this being elaborated on different sorts. As raw material for obtaining filler it was used artificial aggregate sort $0 / 4 \mathrm{~mm}$, which was obtained from blast furnace sludge, crushed and sorted; the raw material is suitable for use in obtaining bituminous mixtures used in the construction of roads, airports and other traffic areas, in accordance with the provisions of SR EN 13043: 2002 / AC: 2004, as it is stated in the certificate for factory production control. In this sense, on the aggregate of origin, laboratory tests were performed according to the current, and the values of the characteristics were determined by laboratory tests. Below are the characteristics of the sludge, relevant for demonstrating the ability to be used as a filler (not all the characteristics were determined on the $0 / 4 \mathrm{~mm}$ fraction).

Table 1

Characteristics determined on blast furnace sludge

\begin{tabular}{|c|c|c||}
\hline Crt no & $\begin{array}{c}\text { Characteristic determined on } \\
\text { furnace sludge }\end{array}$ & $\begin{array}{c}\text { Values of characteristics } \\
\text { obtained from laboratory } \\
\text { tests on furnace sludge }\end{array}$ \\
\hline \hline 1 & $\begin{array}{c}\text { Volumetric mass of bulk (for } \\
\text { fraction 0/63 mm) }\end{array}$ & $1,51 \mathrm{Mg} / \mathrm{mc}$ \\
\hline 2 & $\begin{array}{c}\text { Pre-dried volumetric mass for } \\
\text { fraction 0,063 / 31,5 mm }\end{array}$ & $2,58 \mathrm{Mg} / \mathrm{mc}$ \\
\hline 3 & Freeze-thaw resistance & $2,6 \%$ \\
& - for fraction $4 / 8 \mathrm{~mm}$ & $1,9 \%$ \\
& - for fraction $8 / 16 \mathrm{~mm}$ & $0,7 \%$ \\
\hline 4 & - for fraction $16 / 31,5 \mathrm{~mm}$ & $0,9 \%$ \\
\hline & - for fraction 31,5/63 mm & $34,0 \ldots 46,0 \%$ \\
& Chemical composition & $31,0 \ldots 39,0 \%$ \\
\hline
\end{tabular}




\begin{tabular}{|c|c|c|}
\hline Crt no & $\begin{array}{l}\text { Characteristic determined on } \\
\text { furnace sludge }\end{array}$ & $\begin{array}{l}\text { Values of characteristics } \\
\text { obtained from laboratory } \\
\text { tests on furnace sludge }\end{array}$ \\
\hline & $\begin{array}{c}\text { - aluminum oxide, } \mathrm{Al}_{2} \mathrm{O}_{3} \\
\text { - iron oxide, } \mathrm{FeO} \\
\text { - magnesium oxide, } \mathrm{MgO} \\
\text { - manganese oxide, } \mathrm{MnO} \\
\text { - sulfur in the form of sulfides, } \mathrm{S} \\
\end{array}$ & $\begin{array}{c}11,00 \ldots 21,00 \% \\
0,2 \ldots 0,7 \% \\
\leq 8 \% \\
0,1 \ldots 1,9 \% \\
0,4 \ldots 1,0 \% \\
\end{array}$ \\
\hline 5 & $\begin{array}{c}\text { Chemical character (determination } \\
\text { made by SC Liberty Galati } \\
\text { supplier) }\end{array}$ & $\begin{array}{l}\text { the raw material is } \\
\text { chemically inert, it is } 100 \% \\
\text { ecological, it has no } \\
\text { negative impact on the } \\
\text { environment }\end{array}$ \\
\hline 6 & $\begin{array}{l}\text { Disintegration of granulated sludge } \\
\text { from the furnace, made on the } 0 / 63 \\
\mathrm{~mm} \text { lot, cooled in air from the } \\
\text { dump (determination made by the } \\
\text { SC Liberty Galati supplier) }\end{array}$ & $\begin{array}{l}\text { after immersion in water, no } \\
\text { piece shows cracks or } \\
\text { disintegrations }\end{array}$ \\
\hline
\end{tabular}

Visually analyzing the raw material that will be processed in the laboratory by grinding as a filler, we declare the following characteristics found through visual observations: the raw material is homogeneous, with a compact granular appearance, crystalline, without any impurities of any kind (such as: earth bulbs, coal, clays, etc.). The granules have a polyhedral appearance, are crushed, and have different dimensions included in the $0 / 4 \mathrm{~mm}$ granulation. In order to use the filler in the preparation of asphalt mixtures, the conformity check with the requirements of the standard, through initial type tests, must be carried out. These initial tests will be the starting point for the control of the future output. In the following, according to SR EN 13043, chapter 5, "Characteristics of fillers", we can find out what are the characteristics imposed on the supplemental fillers used in the preparation of the asphalt mix. In this sense, to identify the characteristics on the filler obtained from the BF sludge, we will determine:

a) Characteristics regarding granulosity

The required granulosity of the filler, according to SR EN 13043.

The granulosity of the filler added to the mixture improves the granulosity of the total mineral aggregate, in the way of reducing the volume of voids. Due to its fineness, the filler occupies part of the holes of the aggregates (fine, medium, and large), contributing to the creation of a more compact and more resistant mineral skeleton. The filler added to the asphalt, besides the granulometric role, also has the role of increasing the compaction of the mixture of natural aggregates, therefore an optimum granulation will be finally reflected in the degree of compaction of the mixture. The granulosity is determined by gravimetric sifting through sieves, initially determining the fraction left on the sieves, after which were calculated the passes through those certain sieves, after which those passes 
were converted to percentages of the total analyzed content. The way of meeting these requirements by the studied material: considering that the filler was obtained in the laboratory, by grinding a relatively small quantity, sufficient for physical and chemical analysis (100 g), it was possible to accurately break the rock up to the imposed granulation. According to the tests carried out in the laboratory regarding the particle size of the bf sludge filler, the following values were obtained.

Table 2

Granulosity of blast furnace sludge filelr sample

\begin{tabular}{|c|c|c|}
\hline Crt no & Sieve dimension, in $\mathrm{mm}$ & Results, in \% \\
\hline \hline 1 & Passing through sieve of $2 \mathrm{~mm}$ & 100 \\
\hline 2 & Passing through sieve of $0,125 \mathrm{~mm}$ & 87,9 \\
\hline 3 & Passing through sieve of $0,063 \mathrm{~mm}$ & 76,3 \\
\hline
\end{tabular}
EN 933-9).

Harmful fine particles (test using methylene blue, VBF, according to SR

The defect that can appear in the bituminous road layers due to the presence of impurities or water in the mineral aggregates, is the surface with pits; they represent holes with a diameter of about $20 \mathrm{~mm}$, on small thicknesses or that can even extend all the thickness of the layer. Pits occurs either due to impurities in aggregates, or the presence of soft or altered rocks in the preparation of the asphalt mixture, or because of the presence of water in mineral aggregates. The laboratory tests were performed on the filler, which revealed the content of harmful fine particles as well as the moisture of the filler. According to the SR EN 13043 and AND 605 norms, the following limits were imposed as: for harmful fine particles: methylene blue value vbf $10 \mathrm{~g} / \mathrm{kg}$ (category $\leq 10$ ); humidity: $\max 1 \%$. The methylene blue value of the filler represents the absorption capacity of the methylene blue by the fine powder in aqueous suspension. For this determination, an aqueous solution of methylene blue of a concentration of $10 \pm 0.1 \mathrm{~g} / 1$, distilled water, an amount of $10 \mathrm{~g}$ of dry filler at 105 degree Celsius up to constant mass and cooled to room temperature was used. The mineral powder was mixed in the container with distilled water for 1 minute before determination, as well as throughout the test. With a burette, the solution of methylene blue was added to the vessel, in doses of $5 \mathrm{ml}$, after which, after each dose, the stain test was performed. A drop of the mixture was taken with the aid of a glass rod and placed on the filter paper. Such a stain was made at each dose of methylene blue and the deposit was measured on the paper. Different doses of methylene blue were carried out in suspension, until the test became positive (central deposit surrounded by a light blue halo). After absorption of the methylene blue solution, the test was repeated from minute to minute until the test remained positive for 5 consecutive minutes. At this time, thy were noted: the total volume of the methylene blue solution introduced in the powder suspension, 
in cubic centimeters, mass of the sample in grams, the amount of methylene blue at 1 centimeter of methylene blue solution in grams.

Table 3

Methylene blue test

\begin{tabular}{|c|c|c|}
\hline Crt no & Sieve dimension, in $\mathrm{mm}$ & Results, in \% \\
\hline 1 & $\begin{array}{c}\text { Methylene blue test (on 0/2 mm } \\
\text { fraction) }\end{array}$ & 0,4 \\
\hline
\end{tabular}

b) Physical characteristics

Water content, which should not be more than $1 \%$ by mass.

The moisture of the mineral aggregates plays an important role in the final mixing, because a water content can lead to the formation of clods, to the uncomplete coating of the granules respectively to the formation of pits in the wear layer. Such a mixture put in place favors the infiltration of water into the layer. The humidity was determined by drying in the ventilated oven; the principle was to weigh the filler sample before drying, drying to constant mass (the difference between two weightings did not exceed 0.5 grams) followed by a new weighing. The difference between the determined masses of the wet and dry filler is its humidity. To perform the test, an amount of $500 \mathrm{~g}$ of filler was tested, which was dried in the oven at a temperature of 105 degree Celsius up to the constant mass. Weighing the dry filler was performed after cooling the sample to room temperature. In this phase of analysis of the filler in the laboratory, due to the possibility of drying the material up to the constant mass, it is considered that the humidity is $0 \%$, subject to the fact that it will be taken into account that when preparing the mixture, the humidity of the filler should not be less than $1 \%$.

Pre-dried volumetric mass, declared value.

To prform the test, $10 \mathrm{~g}$ of filler was used which dried in the oven at 110 degree Celsius until constant mass and then allowed to cool, protected from humidity and air currents for 90 minutes. For the determination, only fraction of filler below $0.125 \mathrm{~mm}$ were used. The test sample was introduced into the calibrated and previously weighed pycnometer over which the distilled water was poured until its complete immersion. The pycnometer was then inserted into the absorption vessel, where it was kept for 30 minutes at a pressure of $30 \mathrm{kPa}$; after the sample was brought to normal presses, the capillary tube was fitted, the pycnometer was filled with water until mark and kept at a temperature of 25 degree celsius, for 60 minutes, after which the whole assembly (including the capillary tube) was weighed. The density of the filler was calculated based on the measurements of the mass of the pinometer (full and empty) and the volume of the pycnometer. Pre-dried volumetric mass is a characteristic of the granular material that serves to further determine the actual volumetric mass of the asphalt mixture. Also, this speads over other characteristics of the asphalt mixture in which the filler is used, and which will be analyzed later, determinations that are: 
the volume of voids in the mineral structure, the volume of voids in the asphalt mixture, the volume of voids filled with bitumen. Due to the influence on the predried volumetric mass of the future mixture and implicitly of the volume of voids, this will be reflected in the degree of compaction, in the behavior of the mixture in the layer under the action of traffic.

Table 4

Pre-dried volumetric mass

\begin{tabular}{|c|c|c|}
\hline \hline Crt no & Characteristics determined & Results, in $\mathrm{Mg} / \mathrm{cm}^{3}$ \\
\hline \hline 1 & Pre-dried volumetric mass & 2,589 \\
\hline
\end{tabular}

c) Stiffness characteristics

The porosity of the filler.

The porosity of the filler has a great influence on the asphalt mixing behavior. Due to the micropores in the composition of the filler granules, they can have a reduced hardness, which is expressed by the high porosity. The high porosity filler can change the bitumen properties. The high porosity of the filler is mainly given by the content of impurities in the form of clay (determined by the methylene blue value method) as well as the compounds $\mathrm{Fe}_{2} \mathrm{O}_{3}$ and $\mathrm{Al}_{2} \mathrm{O}_{3}$.

Table 5

Relevant compounds for porosity

\begin{tabular}{|c|c|c||}
\hline \hline Crt no & Characteristics determined & Results \\
\hline \hline 1 & $\begin{array}{c}\text { Clay content (methylene blue test } \\
\text { method), VBF }\end{array}$ & $\begin{array}{c}0,4 \text { grams of methylene } \\
\text { blue solution } / \text { kg of fraction } \\
0 / 0,2 \mathrm{~mm}\end{array}$ \\
\hline 2 & Content of $\mathrm{Fe}_{2} \mathrm{O}_{3}$ compounds & $0,2 \ldots 0,7 \%$ \\
\hline 3 & Content of $\mathrm{Al}_{2} \mathrm{O}_{3}$ compounds & $11,00 \ldots 21,00 \%$ \\
\hline
\end{tabular}

Compared to a limestone filler, from the rock from Arsita Iacobeni quarry, Suceava county, one can observe the relatively high difference of the content of $\mathrm{Al}_{2} \mathrm{O}_{3}$, respectively the limestone filler has a content of $1.67 \%$ compared to that of the $11.00 \ldots 21.00 \%$ of bf sludge, which means a content of 6 to 12 times higher oxide content. The $\mathrm{Fe}_{2} \mathrm{O}_{3}$ contents of the two materials analyzed comparatively, strictly on the nature of the rock criterion, are relatively equal, the limestone filler having $0.47 \% \mathrm{Fe}_{2} \mathrm{O} 3$. In this situation, it is necessary to pay special attention to the interaction of the filer bitumen, respectively of the dosage of filer - bitumen in the mixing mixture, taking into account the possibility of increasing the optimal bitumen content in the mix prepared with filler from the bf sludge compared to the one prepared from limestone.

d) Chemical characteristics.

Water solubility. 
For the determination, a filler sample was prepared, with a mass of 25 grams, after which it was dried to a constant mass at 110 degree Celsius. The test samples were placed in two $500 \mathrm{ml}$ Erlenmeyer glasses, weighed together with the contents and their weigh was recorded. The mass of the dry filler from each glass resulted from the difference. In each glass a quantity of water equal to half the mass of the test tube was added. The coated specimens were stirred continuously to avoid sedimentation for $24 \mathrm{~h}$. After the time expired, the liquid was filtered from above, leaving the residue in the glasses. The residue left in both the glass, the funnel and the filter paper was dried and cooled to room temperature and then weighed again.

Table 6

Water solubility

\begin{tabular}{|c|c|c|}
\hline Crt no & Characteristics determined & Results, in \% \\
\hline \hline 1 & Water solubility & 0,6 \\
\hline
\end{tabular}

e) The fineness of the filler.

The specific surface of the filler by Blain test.

The adsorption phenomenon that occurs at the filer - bitumen interface is represented by the forces of mutual attraction between them. Adsorption can occur through Van der Waals forces, electrostatic attraction forces, dispersion forces, internal quantum mechanical forces (valence bonds) which can create chemistry combinations (chemabsorption). These deposits can occur independently or simultaneously in the dispersed system. The filer interaction, determined by these phenomena listed above, can influence the behavior of the mixture under the act of forces as a result of the stability of the chemical composition of the bituminous mastic (the bitumen-bitumen ratio in asphalt mixture). The components of road bitumen, respectively petroleum, maltenes and asphaltene, have different content of hydrogen, lower in the order of enumeration, and the size of the molecules increases in the order of enumeration. In common bitumen used in Romania, predominantly acidic compounds are found compared to the basic ones. Both the structure and the physical-mechanical properties of the bitumen can be modified by modifying the composition, as the effect of evaporating a part of the petroleum content, oxidation as an effect of oxygen in the air, the action of UV radiation or heat. The intercatin filer - bitumen, respectively the modification of the properties of this mastic is influenced by the specific surface of the filler. Also, the modification of the properties of the bitumen following the inertia of the filer bitumen, can also lead to the modification of the filler behavior in asphalt mixture, it can change the stability, the degree of dispersion of the filler. The specific surface of the filler represents the total surface of the filler particles contained in its mass unit. The surface of the filler always contains cracks, pores, bumps of microscopic dimensions. The granules are porous, the pores being both on the surface and closed, labyrinthine, 
connected between them. The closed porosity does not contribute to the adsorption phenomenon in the filler-binder mixture, while the open porosity, specially the one with dimensions up to $100 \mu$, represents a relatively large surface compared to the total surface of the granule, which will influence the bitumen absorption phenomenon at the top of the filler granules. The active points on the surface of the filler, those that significantly influence its specific surface, are those located in projections, edges, corners as well as in areas with crystalline network defects or defects arising from grinding. These points can lead to adsorption by Van der Waals forces and localized adsorption. In these active points there is a stronger activity of the links with the rest of the network, either due to a number of unmatched intermolecular forces, or due to the unstable structure that reduces the system to a lower energy content. Given these considerations, we can admit that the filler absorbs substances from the environment with which it interacts and with which it is in contact. It is obvious that the shape of the filler granule surface has an influence on its specific surface. The deviation from the sphericity of the granule it is materialized through a multitude of microscopic forms of the granule. The experimental calculations and methods performed to date start from the hypothesis that the granules have a spherical shape. The deviation from the sphericity and the number of active points on the surface can significantly modify the specific surface of the granule, which would implicitly lead to the increase of the adsorption or chemabsorption phenomena. In practice, depending on the nature of the source rock, there were found different shapes of the filler grains, starting from full, hexagonal shapes, with flat and uneven surfaces, with edges and corners, partially rounded at the limestone filler, very rough shapes, with thin edges specific to lime filler, up to the spherical shape of the filler obtained from thermal power plant ash and blocks with many holes evenly distributed and similar in size to the diatomite. Due to the phenomena that appear at the filerbitumen interface, the knowledge of the specific surface of the filer constitutes an appreciation of its quality. The larger its specific surface, the more the influence of the structure of the filler on the bitumen is manifested. In the asphalt mixture, the influence of the specific surface correlated with the fineness of the filler granules can be negative, because, the very fine granules can lead to particle agglomerations in the mixture. These agglomerations have the effect of reducing the compactness of the asphalt mixture. In practice, these effects have been found predominantly in the asphalt mixtures used in the wear layer, especially at the high dosage of filler of the mineral mixture, between $7 \ldots 12 \%$. The other granular materials in the composition of the asphalt mixture have very little influence regarding the specific surface, the predominant being this characteristic of the filler. Blain testing method is one of the current methods used in our country, this is a method of finding the fineness of the filler and as an indirect method of finding the specific surface. On the analyzed sample, the specific surface was determined by Blain test. This test consists in determining the fineness; for this we observe the time required for a fixed quantity of air to pass through a 
compacted filler layer, with specified dimensions and porosity. For the determination a filler sample with a certain known volume and known porosity was performed. The amount of material used resulted from the calculation, so that the porosity is equal to 0,500 . The test consisted of placing the perforated metal disc on the bottom of the cell over which a paper disk was placed and filtered, and then the material was inserted into the cell. The second filter paper disk was placed and the plunger was lowered until its lower face reached the cell. The plunger then lowered again with a low pressure until it reached the cell. After this compaction, the plunger was carefully removed, not to damage the sample. The sample thus prepared was inserted into the test apparatus. After the measurements were made, the temperatures were recorded according to the four times.

Table 7

Finess

\begin{tabular}{|c|c|c|}
\hline Crt no & Characteristics determined & Results, in $\mathrm{cm}^{2} / \mathrm{g}$ \\
\hline \hline 1 & Finess (Blain method) & 5086 \\
\hline
\end{tabular}

f) Emissions of radioactive substances.

The material is chemically inert, $100 \%$ ecological, does not have a negative impact on the environment. material).

g) Durability to freeze/thaw: frost resistance of coarse aggregate (raw

According to the test report performed to the beneficiary of SC Liberty Galati, the test was performed on the coarse aggregate with a dimension over 4 $\mathrm{mm}$. The values were shown at Table 1 .

Comparative analysis of the filler from the furnace sludge and the limestone filler present on the market.

In Romania the limestone filler is used very frequently, the standard according to which its quality is appreciated being the same used for the appreciation of the filler from artificial aggregate. Therefore, it is appropriate to compare the values obtained on the filler from the bf furnace sludge with those of a limestone filler, originating from the limestone type rock, place of ArsitaIacobeni, Suceava county. Comparative table of result values declared on a filler made from natural rock - limestone (Arsita - Iacobeni, Suceava county) and filler obtained from bf sludge (SC Liberty Galati) is shown below.

Table 8

Comparative table of characteristics of two fillers

\begin{tabular}{|c|c|c|c||}
\hline Crt no & Characteristics determined & \multicolumn{2}{|c|}{$\begin{array}{c}\text { Comparactive values } \\
\text { obtained on } \\
\text { BF sludge / limestone filler }\end{array}$} \\
\hline \hline 1 & Pre-dried volumetric mass & $2,589 \mathrm{Mg} / \mathrm{mc}$ & $1,750 \mathrm{Mg} / \mathrm{mc}$ \\
\hline 2 & Granulosity & & \\
\hline
\end{tabular}




\begin{tabular}{|c|c|c|c|}
\hline \multirow[t]{2}{*}{ Crt no } & \multirow{2}{*}{$\begin{array}{c}\text { Characteristics determined } \\
\text { - passing through sieve of } 2 \mathrm{~mm} \\
\text { - passing through sieve of } 0,125 \\
\mathrm{~mm} \\
\text { - passing through sieve of } 0,063 \\
\mathrm{~mm}\end{array}$} & \multicolumn{2}{|c|}{$\begin{array}{c}\text { Comparactive values } \\
\text { obtained on } \\
\text { BF sludge / limestone filler } \\
\end{array}$} \\
\hline & & $\begin{array}{l}100 \% \\
87,9 \% \\
76,3 \%\end{array}$ & $\begin{array}{r}100 \% \\
93,2 \% \\
80,21 \%\end{array}$ \\
\hline 3 & $\begin{array}{l}\text { Harmfull fine particles content } \\
\text { (VBF) }\end{array}$ & $0,4 \%$ & $2,0 \%$ \\
\hline 4 & Water content & $0 \%$ & $0,4 \%$ \\
\hline 5 & Blain test. Specific surface & $5086 \mathrm{~cm}^{2} / \mathrm{g}$ & $4276 \mathrm{~cm}^{2} / \mathrm{g}$ \\
\hline 6 & Water solubility & $0,09 \%$ & $0,17 \%$ \\
\hline 7 & $\begin{array}{c}\text { Chemical composition: } \\
\text { - calcium oxide, } \mathrm{CaO} \\
\text { - silicon dioxide, } \mathrm{SiO}_{2} \\
\text { - aluminum oxide, } \mathrm{Al}_{2} \mathrm{O}_{3} \\
\text { - iron oxide, } \mathrm{FeO} \\
\text { - magnesium oxide, } \mathrm{MgO} \\
\text { - manganese oxide, } \mathrm{MnO} \\
\text { - sulfur in the form of sulfides, } \mathrm{S}\end{array}$ & $\begin{array}{c}34-46 \% \\
31-39 \% \\
11-21 \% \\
0,2 \ldots 0,7 \% \\
\leq 8 \% \\
0,1 \ldots 1,9 \% \\
0,4 \ldots 1,0 \%\end{array}$ & $\begin{array}{c}51,54 \% \\
4,25 \% \\
1,67 \% \\
0,47 \% \\
0,10 \% \\
- \\
0,09 \% \\
\end{array}$ \\
\hline 8 & Chemical character & $\begin{array}{c}\text { the raw } \\
\text { material is } \\
\text { chemically } \\
\text { inert, it is } \\
100 \% \\
\text { ecological, it } \\
\text { has no } \\
\text { negative } \\
\text { impact on the } \\
\text { environment }\end{array}$ & $\begin{array}{l}\text { limestone } \\
\text { rock }\end{array}$ \\
\hline
\end{tabular}

The results of the two materials being comparable, and due to the fact that the filler obtained from bf sludge complies with the requirements of the standard on which it was verified, SR EN 13043, we can conclude that it has the ability to be used in the preparation of asphalt mixtures, to be analyzed the way of his behavior in interaction with bitumen, as well as in the total compounds of asphalt mixture. The possibility of using a material from the metallurgical industry, material that is currently stored in dumps in the SC Liberty Galati space, will offer future advantages such as: the guarantee of the elimination of these deposits, introduction in the life cycle of some products from warehouses, avoiding environmental problems and including penalties for deposits. By usind the steel waste obtained from the steelworks, favorable results can be obtained both in terms of economic development as well as the valorization of a material that,if is not being used, is treated as waste. Currently, there is a tendency to 
exploit bf sludge waste, due to its ability to be used as an artificial aggregate in the construction industry, bf sludge being processed (crushed and sorted) in different dimensions and used as granular material especially in foundations. Blast furnace sludge is the result of the technological process of obtaining castings, by granulation. During the technological process, the sludge is liquid and has a temperature of approximately 1480 degrees Celsius. The sludge granulation process is obtained by hydrodynamic shock resulting in the granulated sludge product. Also, the granulated sludge can be crushed and sorted later to obtain the sorts. After granulation in the water of the sludge, it is removed from the basin with the excavators and stored on platforms, to drain water. For the bf sludge filler producer, the possibility of using this material as a raw material gives it the opportunity to: partially substitute the fuels used to support the raw material (stone quarrying), to be actively involved in the procedures for the protection of the environment. For the society, the possibility of using the granulated sludge will bring benefits amount: conservation of natural resources (quarry rock, the most commonly used rock in Romania in the production of filler), reducing the impact on the environment, by removing the dumps from the deposits, avoiding overcrowding of the material in deposits.

\section{Conclusions}

As it results from the tests carried out and from the theoretical considerations described in this chapter, the filler plays an important role in the construction of asphalt mixtures. The fineness properties and the inert character of the filler highlight the process of inertial interaction in the mixture. This is why it is important to establish the characteristics of the filler before placing it in the mixture, in order not to compromise the quality of the mixture made. We can conclude after this study, the role that the filler has in mixtures and the effect of its characteristics on the prepared mixture, as follows: it leads to the improvement of the granulosity of the mineral mixture, it leads to the delay of the aging phenomenon of the bitumen, it leads to the increase of the stability of the asphalt mixture and to the decrease of the deformation, it improves the adhesive of the binder, the porosity of the filler influences the binder dosage and the mixing behavior; if necessary, in order to decrease the porosity of the filler, it is possible to use activating substances in its grinding process (in production), the porosity of the particles is affected by their shape; the particle shape also influences the adhesive bonding to the granule surface.

Appreciation of the quality of the filler from the bf sludge granule, from SC Liberty Galati plant.

The assessment of the quality of the filler obtained according to the provisions of SR EN 13043, respectively the conditions fulfilled by the bf sludge filler, according to the standard domain of application, are those described in table below. 
Table 9

Essential characteristics fulfilled by bf sludge filler

\begin{tabular}{|c|c|c|c|}
\hline Crt no & \multicolumn{2}{|c|}{ Essential characteristics } & Results \\
\hline \multirow[t]{3}{*}{1} & $\begin{array}{c}\text { Finess / } \\
\text { dimension and } \\
\text { volumetric mass } \\
\text { of granules }\end{array}$ & Granulosity & $\begin{array}{c}\text { - passing through sieve of } 2 \\
\text { mm: } 100 \% \\
\text { - passing through sieve of } \\
0,125 \mathrm{~mm}: 87,9 \% \\
\text { - passing through sieve of } \\
0,063 \mathrm{~mm}: 76,3 \%\end{array}$ \\
\hline & & Blain test & $5086 \mathrm{~cm}^{2} / \mathrm{g}$ \\
\hline & & $\begin{array}{c}\text { Pre-dried } \\
\text { volumetric mass }\end{array}$ & $2,589 \mathrm{Mg} / \mathrm{m}^{3}$ \\
\hline 2 & Purity & $\begin{array}{c}\text { Harmfull fine } \\
\text { particles }\end{array}$ & $\begin{array}{c}0,4 \mathrm{~g} \text { solution of blue } \\
\text { methylene / } \mathrm{kg} \text { fraction of } \\
0 / 0,2 \mathrm{~mm}\end{array}$ \\
\hline 3 & Water solubility & Water solubility & $0,6 \%$ \\
\hline 4 & $\begin{array}{l}\text { Emissions of } \\
\text { radioactive } \\
\text { substance }\end{array}$ & $\begin{array}{l}\text { Raw material } \\
\text { identification }\end{array}$ & $\begin{array}{l}\text { Artificial rock made from bf } \\
\text { sludge, chemically inert, } \\
\text { with zero emmisions of } \\
\text { radioactive substance }\end{array}$ \\
\hline 5 & $\begin{array}{l}\text { Disintegration } \\
\text { of granulated } \\
\text { sludge from the } \\
\text { furnace, made } \\
\text { on the } 0 / 63 \mathrm{~mm} \\
\text { lot, cooled in air } \\
\text { from the dump } \\
\text { (determination } \\
\text { made by the } \\
\text { supplier SC } \\
\text { Liberty) }\end{array}$ & $\begin{array}{l}\text { Disintegration } \\
\text { of particles }\end{array}$ & $\begin{array}{c}\text { After immersion in water, } \\
\text { no piece shows cracks or } \\
\text { disintegrations }\end{array}$ \\
\hline 6 & $\begin{array}{l}\text { Resistance to } \\
\text { freeze-thaw }\end{array}$ & $\begin{array}{c}\text { Resistante to } \\
\text { freeze-thaw test } \\
\text { made on: } \\
\text { - on } 4 / 8 \mathrm{~mm} \\
\text { fraction } \\
\text { - on } 8 / 16 \mathrm{~mm} \\
\text { fraction } \\
\text { - on } 16 / 31,5 \mathrm{~mm} \\
\text { farction } \\
\text { - on } 31,5 / 63 \mathrm{~mm} \\
\text { fraction }\end{array}$ & $\begin{array}{l}2,6 \% \\
1,9 \% \\
0,7 \% \\
0,9 \%\end{array}$ \\
\hline
\end{tabular}


Acknowledgements.

Regards to Mihai Ciobotaru, Chief of Non-Steel Sales Area, Procurement Logistics\&Non-Steel Sales Department, Non-Steel Sales Office for offering technical documentation about conformity certificate of plant production control of crushed aggregates from bf sludge.

\section{REFERENCES}

** SR EN 13043 din noiembrie 2003 Agregate pentru amestecuri bituminoase şi pentru finisarea suprafeţelor, utilizate la construcţia şoselelor, a aeroporturilor şi a altor zone cu trafic.

$*^{*}{ }^{*}$ Indicativ AND 605 din 2016 Normativ privind mixturile asfaltice executate la cald. Condiţii tehnice de proiectare, preparare şi punere în opera a mixturilor Agregate pentru amestecuri bituminoase şi pentru finisarea suprafeţelor, utilizate la construcţia şoselelor, a aeroporturilor şi a altor zone cu trafic.

$*^{*} *$ Certificat de conformitate a controlului producţiei în fabrică. Agregate artificiale din zgură de furnal concasate şi sortate.

\section{INREGISTRARI PRIVIND ZGURA GRANULATA DE FURNAL CU UTILIZARE POTENTIALA CA FILER IN COMPOZITIA MIXTURILOR ASFALTICE}

Scopul studiului de cercetare efectua este de a dezvolta o nouă perspectivă asupra utilizării unui material provenit din industria metalurgică. În prezent, zgura granulată de furnal produsa la Galaţi este utilizată ca material granular ce intră în general în alcătuirea straturilor de fundaţie. Zgura granulată are proprietaţile chimice şi mecanice pentru a fi utilizată ca filer în amestecurile bituminoase, ca rezultat al proprietăţilor sale cum sunt compoziţia, care nu interacţionează cu bitumul, şi abilitatea de a fi concasată în fracţiuni granulare. Principalii constituienţi ai zgurii sunt diferiţi oxizi cum sunt oxid de calciu, aluminiu, fier, magneziu, sulf. Materia primă este omogenă, fără impurităţi şi nu este toxică pentru mediul inconjurator. Caracteristicile probei de filer analizată au fost comparate cu cele din standardele în vigoare. Zgura granulată a fost macinată în fracţiuni foarte fine, sub $2 \mathrm{~mm}$, şi apoi testate în laborator în conditii standard. 